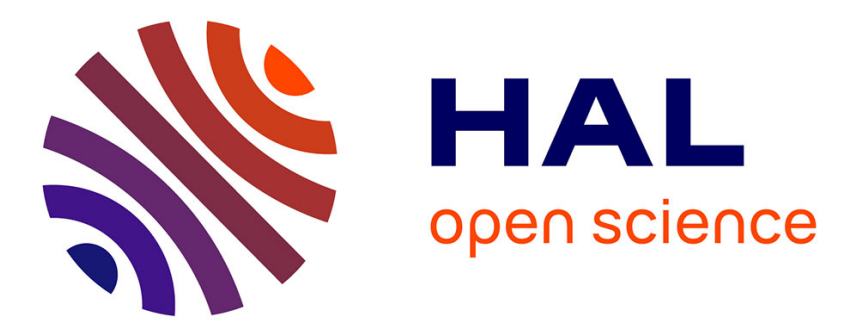

\title{
A Comparison of Symmetrical and Asymmetrical Three-Phase H-Bridge Multilevel Inverter for DTC Induction Motor Drives
}

Farid Khoucha, Mouna Lagoun, Abdelaziz Kheloui, Mohamed Benbouzid

\section{- To cite this version:}

Farid Khoucha, Mouna Lagoun, Abdelaziz Kheloui, Mohamed Benbouzid. A Comparison of Symmetrical and Asymmetrical Three-Phase H-Bridge Multilevel Inverter for DTC Induction Motor Drives. IEEE Transactions on Energy Conversion, 2011, 26 (1), pp.64-72. 10.1109/TEC.2010.2077296 . hal00567261

\section{HAL Id: hal-00567261 https://hal.science/hal-00567261}

Submitted on 19 Feb 2011

HAL is a multi-disciplinary open access archive for the deposit and dissemination of scientific research documents, whether they are published or not. The documents may come from teaching and research institutions in France or abroad, or from public or private research centers.
L'archive ouverte pluridisciplinaire HAL, est destinée au dépôt et à la diffusion de documents scientifiques de niveau recherche, publiés ou non, émanant des établissements d'enseignement et de recherche français ou étrangers, des laboratoires publics ou privés. 


\title{
A Comparison of Symmetrical and Asymmetrical Three-Phase H-Bridge Multilevel Inverter for DTC Induction Motor Drives
}

\author{
Farid Khoucha, Mouna Soumia Lagoun, Abdelaziz Kheloui, \\ and Mohamed El Hachemi Benbouzid, Senior Member, IEEE
}

\begin{abstract}
Earlier studies have pointed out the limitations of conventional inverters, especially in high-voltage and high-power applications. In recent years, multilevel inverters are becoming increasingly popular for high-power applications due to their improved harmonic profile and increased power ratings. Several studies have been reported in the literature on multilevel inverters topologies, control techniques, and applications. However, there are few studies that actually discuss or evaluate the performance of induction motor drives associated with three-phase multilevel inverter. This paper presents then a comparison study for a cascaded H-bridge multilevel direct torque control (DTC) induction motor drive. In this case, symmetrical and asymmetrical arrangements of five- and seven-level $\mathrm{H}$-bridge inverters are compared in order to find an optimum arrangement with lower switching losses and optimized output voltage quality. The carried out experiments show that an asymmetrical configuration provides nearly sinusoidal voltages with very low distortion, using less switching devices. Moreover, torque ripples are greatly reduced.
\end{abstract}

Index Terms-Direct torque control (DTC), induction motor, multilevel inverters.

\section{INTRODUCTION}

$\mathbf{M}$ ULTILEVEL voltage-source inverters are intensively studied for high-power applications [1], [2], and standard drives for medium-voltage industrial applications have become available [3], [4]. Solutions with a higher number of output voltage levels have the capability to synthesize waveforms with a better harmonic spectrum and to limit the motor winding insulation stress. However, their increasing number of devices tends to reduce the power converter overall reliability and efficiency. On the other hand, solutions with a low number

Manuscript received July 2, 2009; revised November 7, 2009, April 23, 2010, and August 26, 2010; accepted September 8, 2010. Date of publication October 7, 2010; date of current version February 18, 2011. Paper no. TEC-00263-2009.

F. Khoucha is with the University of Brest, EA 4325 LBMS, CS 93837, 29238 Brest Cedex 03, France and also with the Electrical Engineering Department, Polytechnic Military Academy, 16111 Algiers, Algeria (e-mail: fkhoucha@yahoo.fr).

M. S. Lagoun is with the University of Brest, EA 4325 LBMS, CS 93837 , 29238 Brest Cedex 03, France and also with the University of Laghouat, 03000 Laghouat, Algeria (e-mail: lagoun_mona@yahoo.fr).

M. E. H. Benbouzid is with the University of Brest, EA 4325 LBMS, CS 93837, 29238 Brest Cedex 03, France (e-mail: Mohamed.Benbouzid@univbrest.fr).

A. Kheloui is with the Electrical Engineering Department, Polytechnic Military Academy, 16111 Algiers, Algeria (e-mail: aziz_kheloui@yahoo.fr).

Color versions of one or more of the figures in this paper are available online at http://ieeexplore.ieee.org.

Digital Object Identifier 10.1109/TEC.2010.2077296 of levels either need a rather large and expensive $L C$ output filter to limit the motor winding insulation stress, or can only be used with motors that do withstand such stress. The various voltage stages have been chosen after considering the real-power contribution of the highest voltage stage. The maximum power supplied by highest voltage stage is maintained below the load power.

Many studies have been conducted toward improving multilevel inverter. Some studies dealt with innovative topologies, such as cascaded multilevel inverter, to optimize the components utilization and the asymmetrical multilevel inverter to improve the output voltage resolution [5]. Other studies focused on developing advanced control strategies or upgrading the voltagesource inverter strategies for implementation in multilevel inverter [6], [7].

In symmetrical multilevel inverter, all $\mathrm{H}$-bridge cells are fed by equal voltages, and hence all the arm cells produce similar output voltage steps. However, if all the cells are not fed by equal voltages, the inverter becomes an asymmetrical one. In this inverter, the arm cells have different effect on the output voltage. Other topologies are possible, such as the neutral point clamped fed by unequal capacitors.

Asymmetrical multilevel inverter has been recently investigated [8], [9]. In all these studies, H-bridge topology has been considered and a variety of selection of cascaded cell numbers and dc-sources ratios have been adopted [8]. The suggested pulsewidth-modulation strategy that maintains the high-voltage stage to operate at low frequency limits the source-voltage selection.

One of the methods that have been used by a major multilevel inverter manufacturer is direct torque control (DTC), which is recognized today as a high-performance control strategy for ac drives [10]-[13]. Several authors have addressed the problem of improving the behavior of DTC ac motors, especially by reducing the torque ripple. Different approaches have been proposed [14]. Although these approaches are well suitable for the classical two-levels inverter, their extension to a greater number of levels is not easy. Throughout this paper, a theoretical background is used to design a strategy compatible with hybrid cascaded H-bridge multilevel inverter; symmetrical and asymmetrical configuration are implemented and compared [15]. Experimental results obtained for an asymmetrical inverter-fed induction motor confirm the high dynamic performance of the used method, presenting good performances and very low torque ripples. 


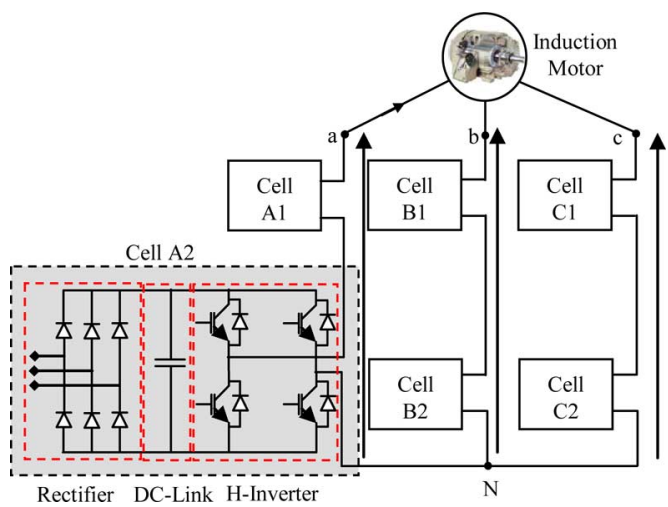

Fig. 1. Structure of two-cells cascaded multilevel inverter.

\section{CASCADEd H-Bridges StRUCture AND OPERATION}

The cascaded H-bridge inverter consists of power conversion cells, each supplied by an isolated dc source on the dc side, which can be obtained from batteries, fuel cells, or ultracapacitors [15]-[17], and series-connected on the ac side. The advantage of this topology is that the modulation, control, and protection requirements of each bridge are modular. It should be pointed out that, unlike the diode-clamped and flying-capacitor topologies, isolated dc sources are required for each cell in each phase. Fig. 1 shows a three-phase topology of a cascade inverter with isolated dc-voltage sources. An output phase-voltage waveform is obtained by summing the bridges output voltages

$$
v_{o}(t)=v_{o, 1}(t)+v_{o, 2}(t)+\cdots+v_{o, N}(t)
$$

where $N$ is the number of cascaded bridges.

The inverter output voltage $v_{o}(t)$ may be determined from the individual cells switching states

$$
v_{o}(t)=\sum_{j=1}^{N}\left(\mu_{j}-1\right) V_{\mathrm{dc}, j}, \quad \mu_{j}=0,1, \ldots
$$

If all dc-voltage sources in Fig. 1 are equal to $V_{\mathrm{dc}}$, the inverter is then known as a symmetric multilevel one. The effective number of output voltage levels $n$ in symmetric multilevel inverter is related to the cells number by

$$
n=1+2 N
$$

For example, Fig. 2 illustrated typical waveforms of Fig. 1 multilevel inverter with two dc sources (five-levels output). The maximum output voltage $V_{\mathrm{o}, \mathrm{Max}}$ is then

$$
V_{\mathrm{o}, \mathrm{MAX}}=N V_{\mathrm{dc}} .
$$

To provide a large number of output levels without increasing the number of inverters, asymmetric multilevel inverters can be used.

In [18] and [19], it is proposed to chose the dc-voltages sources according to a geometric progression with a factor of 2 or 3 . For $N$ of such cascade inverters, one can achieve the
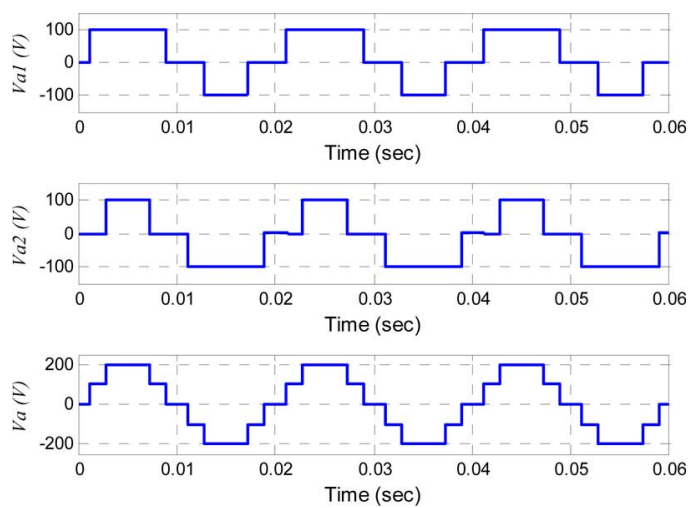

Fig. 2. Symmetric multilevel inverter with five-levels output voltage synthesis.
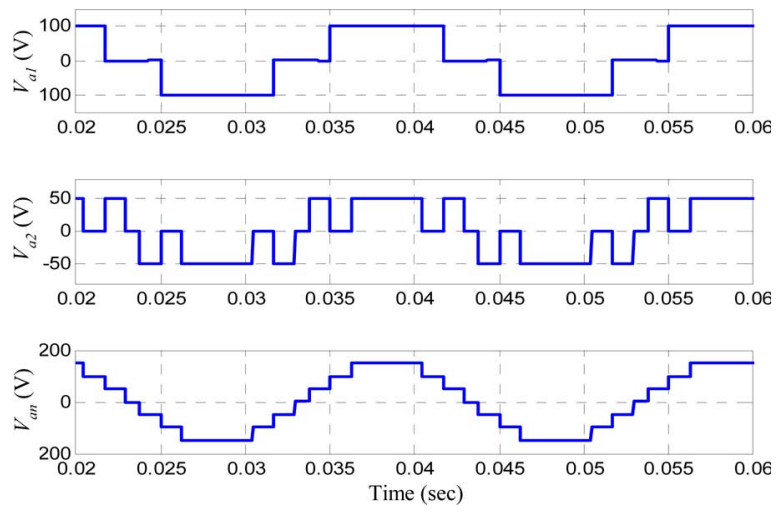

Fig. 3. Asymmetric multilevel inverter with seven-levels output voltage synthesis.
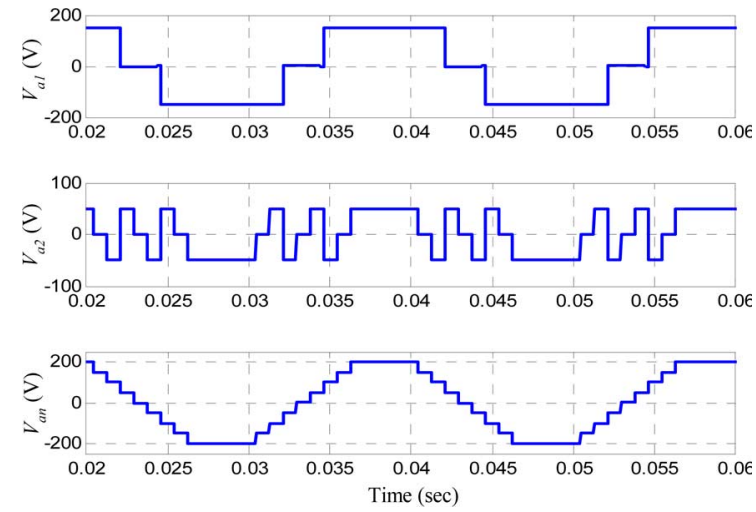

Fig. 4. Asymmetric multilevel inverter with nine-levels output voltage synthesis.

following distinct voltage levels

$\left\{\begin{array}{lll}n=2^{N+1}-1, & \text { if } V_{\mathrm{dc}, j}=2^{j-1} V_{\mathrm{dc}}, & j=1,2, \ldots, N \\ n=3^{N}, & \text { if } V_{\mathrm{dc}, j}=3^{j-1} V_{\mathrm{dc}}, & j=1,2, \ldots, N .\end{array}\right.$

For example, Figs. 3 and 4 illustrated typical waveforms of Fig. 1 multilevel inverter with, respectively, two dc sources $\left(V_{\mathrm{dc}}\right.$ and $\left.2 V_{\mathrm{dc}}\right)$ (seven-levels output) and two dc sources ( $V_{\mathrm{dc}}$ and $\left.3 V_{\mathrm{dc}}\right)$ (nine-levels output). 
TABLE I

COMPARISON OF MULTILEVEL INVERTERS

\begin{tabular}{|c|c|c|c|}
\hline & \multirow{2}{*}{$\begin{array}{c}\text { Symmetrical } \\
\text { inverter }\end{array}$} & \multicolumn{2}{|c|}{ Asymmetrical inverter } \\
\cline { 3 - 4 } & $2 N+1$ & $2^{N+1}-1$ & $3^{N}$ \\
\hline$N$ & $N$ & $N$ & $N$ \\
DC sources number & $4 N$ & $4 N$ & $4 N$ \\
Switches number & $4 N$ & $2^{N}-1$ & $\left(3^{N}-1\right) / 2$ \\
$V_{o, M A X}[\mathrm{pu}]$ & $N$ & &
\end{tabular}

The maximum output voltage of these $N$ cascaded multilevel inverters is

$$
V_{o, \operatorname{MAX}}=\sum_{j=1}^{N} V_{\mathrm{dc}, j} .
$$

Equation (6) can be rewritten as

$$
\left\{\begin{array}{l}
V_{o, \mathrm{MAx}}=\left(2^{N}-1\right) V_{\mathrm{dc}}, \\
\quad \text { if } V_{\mathrm{dc}, j}=2^{j-1} V_{\mathrm{dc}}, \\
V_{o, \mathrm{MAx}}=\left(\frac{3^{N}-1}{2}\right) V_{\mathrm{dc}},
\end{array}\right.
$$

Comparing (3) to (7), it can be seen that asymmetrical multilevel inverters can generate more voltage levels and higher maximum output voltage with the same number of bridges.

Table I summarizes the number of levels, switches, dc sources, and maximum available output voltages for classical cascaded multilevel inverters.

Increasing the number of levels provides more steps; hence, the output voltage will be of higher resolution and the reference sinusoidal output voltage can be better achieved. Among the $n^{3}$ switching states of $n$-level inverter, there is $n$ zero states, where zero output voltages are produced. Among the $\left(n^{3}-n\right)$ nonzero remaining states, there are unique states and mutual states. The unique states provide voltage vectors that cannot be obtained by any other states. The mutual state on the other hand, provides a set of output voltages that can be provided by some other mutual state or states. The equivalent mutual states share the same voltage vectors. The $n$-level inverter has $\left[(n-1)^{3}-(n-1)\right]$ nonzero mutual states. The voltage vectors of the five-level inverter are shown in Fig. 5. The number of distinct voltage vectors obtained from $n$-level inverter is $\left[n^{3}-(n-1)^{3}\right]$. The existence of equivalent mutual states has usually been used to minimize the switching losses. Nevertheless, the equivalent mutual states can be replaced by any one of these states and the other states can be considered redundant. There are $(n-1)^{3}$ redundant states in the $n$-level symmetrical H-bridge multilevel inverter.

\section{INDUCTION MOTOR DIRECT TORQUE CONTROL}

DTC is an alternative method to flux-oriented control [12]. However, in the standard version, important torque ripple is obtained even at high sampling frequencies. Moreover, the inverter

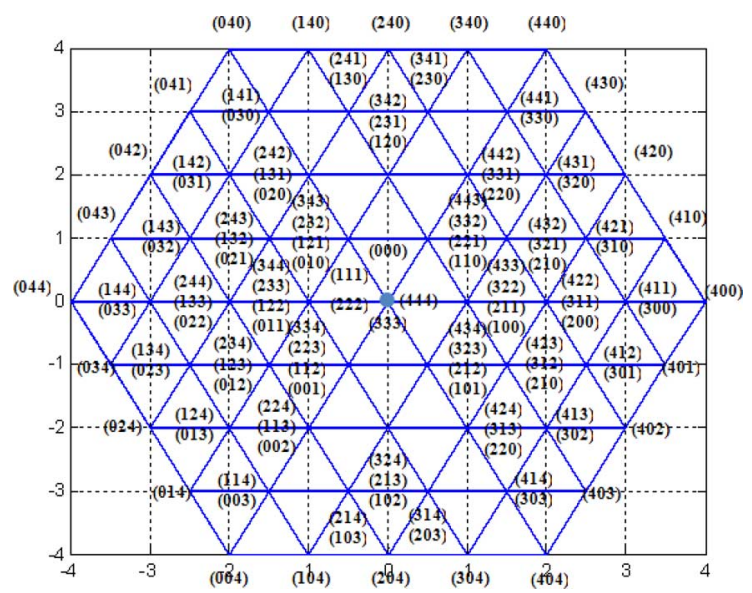

Fig. 5. Voltage vectors of various states of the symmetrical five-levels inverter.

switching frequency is inherently variable and very dependent on torque and shaft speed. This produces torque harmonics with variable frequencies and an acoustic noise with disturbance intensities very dependent on these mechanical variables and particularly grating at low speed. The additional degrees of freedom (space vectors, phase configurations, etc.) provided by the multilevel inverter should, therefore, be exploited by the control strategy in order to reduce these drawbacks [6], [15].

\section{A. Nomenclature}

$\begin{array}{ll}v_{s} & \text { Stator voltage vector. } \\ \phi_{s}\left(\phi_{r}\right) & \text { Stator (rotor) flux vector. } \\ T_{e} & \text { Electromagnetic torque. } \\ R_{s} & \text { Stator resistance. } \\ L_{s}\left(L_{r}\right) & \text { Stator (rotor) inductance. } \\ L_{m} & \text { Magnetizing inductance. } \\ \sigma & \text { Total leakage coefficient, } \sigma=1-L_{m}^{2} / L_{s} L_{r} . \\ \theta_{\mathrm{sr}} & \text { Angle between stator and rotor flux vectors. } \\ p & \text { Pole pair number. }\end{array}$

\section{B. Torque and Flux Estimation}

The stator flux vector an induction motor is related to the stator voltage and current vectors by

$$
\frac{d \phi_{s}(t)}{d t}=v_{s}(t)-R_{s} i_{s}(t)
$$

Maintaining $v_{s}$ constant over a sample time interval and neglecting the stator resistance, the integration of (10) yields

$$
\Delta \phi_{s}(t)=\phi_{s}(t)-\phi_{s}(t-\Delta t)=\int_{t-\Delta t}^{t} v_{s} \Delta t .
$$

Equation (9) reveals that the stator flux vector is directly affected by variations on the stator voltage vector. On the contrary, the influence of $v_{s}$ over the rotor flux is filtered by the rotor and stator leakage inductance [20], and is, therefore, not relevant over a short-time horizon. Since the stator flux can be changed quickly while the rotor flux rotates slower, the angle between both vectors $\theta_{\text {sr }}$ can be controlled directly by $v_{s}$. A graphical representation of the stator and rotor flux dynamic behavior is 


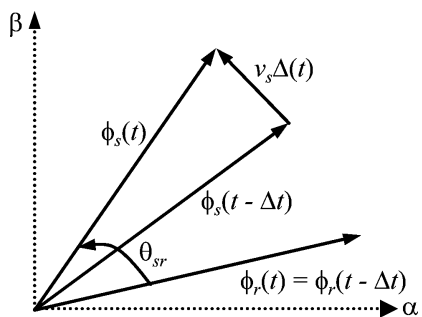

Fig. 6. Influence of $v_{s}$ over $\phi_{s}$ during a simple interval $\Delta t$.

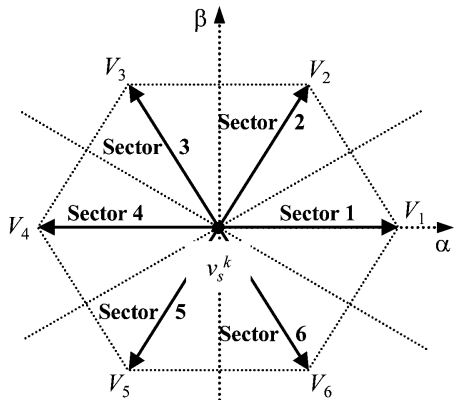

Fig. 7. Possible voltage changes $\Delta v_{s}^{k}$ that can be applied from certain $v_{s}^{k}$.

illustrated in Fig. 6. The exact relationship between stator and rotor flux shows that keeping the amplitude of $\phi_{s}$ constant will produce a constant flux $\phi_{r}$ [21].

Since the electromagnetic torque developed by an induction motor can be expressed by [22]

$$
T_{e}=\frac{3}{2} p \frac{L_{m}}{\sigma L_{s} L_{r}} \phi_{s} \phi_{r} \sin \theta_{\mathrm{sr}}
$$

it follows that change in $\theta_{\mathrm{sr}}$ due to the action of $v_{s}$ allows for direct and fast change in the developed torque. DTC uses this principle to achieve the induction motor desired torque response, by applying the appropriate stator voltage vector to correct the flux trajectory.

\section{Voltage Vector Selection [6], [15]}

Fig. 7 illustrates one of the 127 voltage vectors generated by the inverter at instant $t=k$, denoted by $v_{s}^{k}$ (central dot). The next voltage vector, to be applied to the load $v_{s}^{k+1}$, can be expressed by

$$
v_{s}^{k+1}=v_{s}^{k}+\Delta v_{s}^{k}
$$

where $\Delta v_{s}^{k}=\left\{v_{i} \mid i=1, \ldots, 6\right\}$. Each vector $v_{i}$ corresponds to one corner of the elemental hexagon illustrated in gray and by the dashed line in Fig. 7.

The task is to determine which $v_{s}^{k+1}$ will correct the torque and flux responses, knowing the actual voltage vector $v_{s}^{k}$, the torque and flux errors $e_{\phi}^{k}$ and $e_{T}^{k}$, and the stator flux vector position (sector determined by angle $\theta_{s}$ ). Note that the next voltage vector $v_{s}^{k+1}$ applied to the load will always be one of the six closest vectors to the previous $v_{s}^{k}$; this will soften the actuation effort and reduce high dynamics in torque response due to possible large changes in the reference. Table II summa-
TABLE II

VOLTAGE-VECTOR-SELECTION LOOKUP TABLE

\begin{tabular}{|c|c|c|c|c|}
\hline \multirow{2}{*}{ Sector } & \multicolumn{4}{|c|}{$\operatorname{sign}\left(e_{\phi}{ }^{k}, e_{T}^{k}\right)$} \\
\cline { 2 - 5 } & $(+,+)$ & $(+,-)$ & $(-,+)$ & $(-,-)$ \\
\hline 1 & $V_{2}$ & $V_{6}$ & $V_{3}$ & $V_{5}$ \\
\hline 2 & $V_{3}$ & $V_{1}$ & $V_{4}$ & $V_{6}$ \\
\hline 3 & $V_{4}$ & $V_{2}$ & $V_{5}$ & $V_{1}$ \\
\hline 4 & $V_{5}$ & $V_{3}$ & $V_{6}$ & $V_{2}$ \\
\hline 5 & $V_{6}$ & $V_{4}$ & $V_{1}$ & $V_{3}$ \\
\hline 6 & $V_{1}$ & $V_{5}$ & $V_{2}$ & $V_{4}$ \\
\hline
\end{tabular}

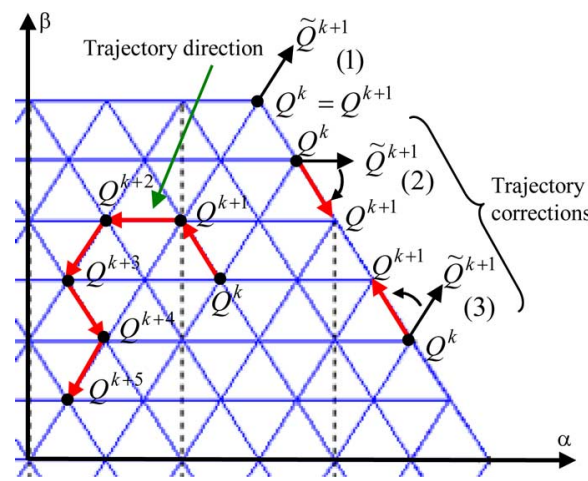

Fig. 8. Optimal space vector tracking and trajectory correction in the stationary $\alpha-\beta$ frame.

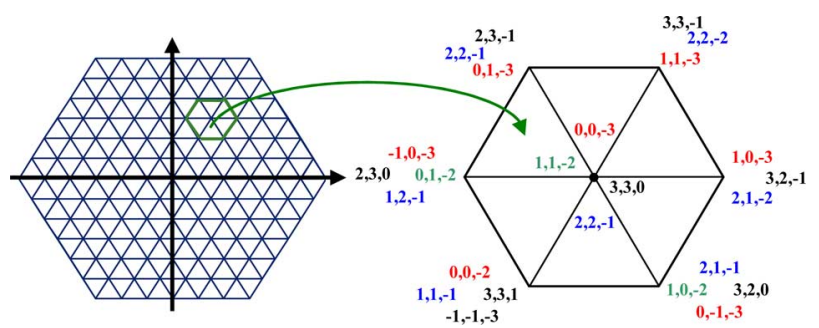

Fig. 9. Space vector and sequences of a seven-levels cascaded H-bridge inverter.

rizes vector selections for the different sectors and comparators output (desired $\phi_{s}$ and $T_{e}$ corrections).

To implement the DTC of the induction motor fed by a hybrid H-bridge multilevel inverter, one should determine at each sampling period, the inverter switch logic states as a function of the torque and flux instantaneous values for the selection of the space vector in the $\alpha-\beta$ frame [23], [24]. The proposed control algorithm was divided into two major tasks, which are independent and executed in cascade.

1) First task: It aims at the control of the electromagnetic state of the induction motor. The torque and flux instantaneous values, and their variations will be taken into account for the space vector selection in the $\alpha-\beta$. Once the space is chosen, the phase levels sequence can be selected. To ensure this task, one should detect the space vector position in the $\alpha-\beta$ frame ( $Q^{k}$ at sampling time $k$ ). The algorithm must then select the next position $Q^{k+1}$ to be achieved before next sampling instant $k+1$ (see Fig. 8) in order to reduce voltage steps magnitude. Only one step displacement 


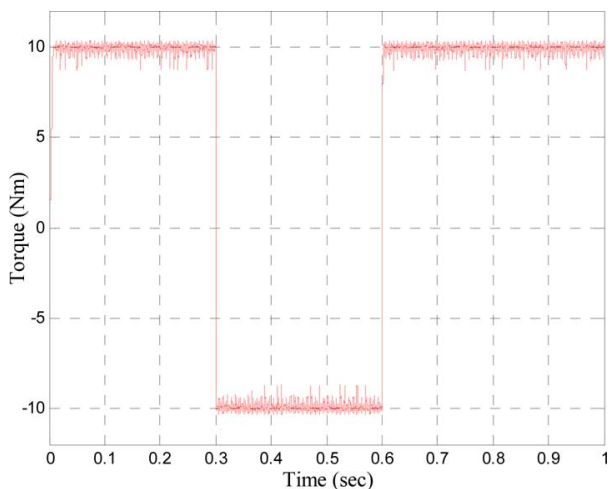

Fig. 10. Five-levels cascaded H-bridge inverter estimated torque waveform.

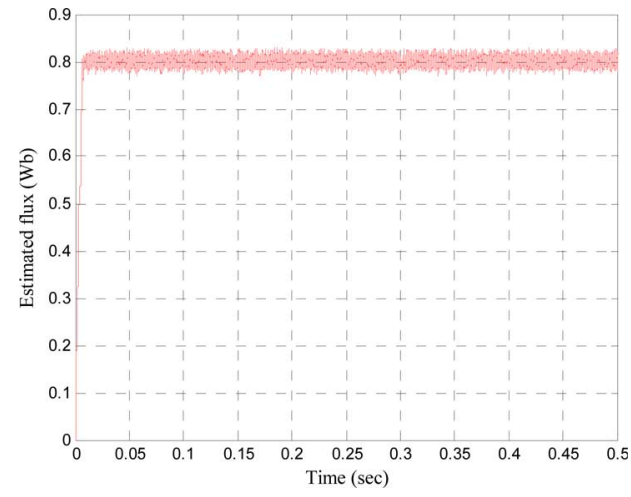

Fig. 11. Five-levels cascaded H-bridge inverter stator flux waveform.

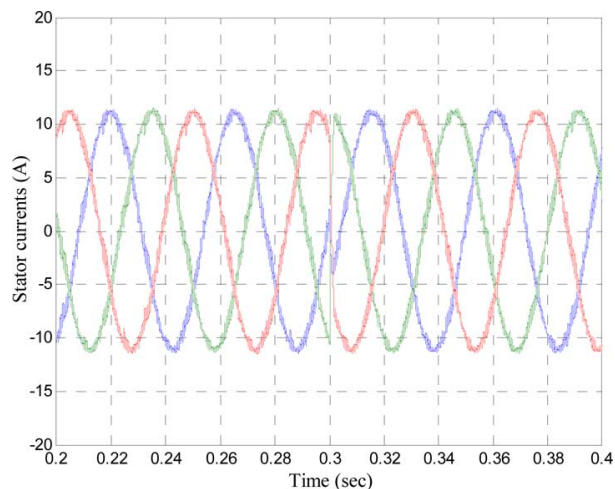

Fig. 12. Five-levels cascaded H-bridge inverter output current waveform.

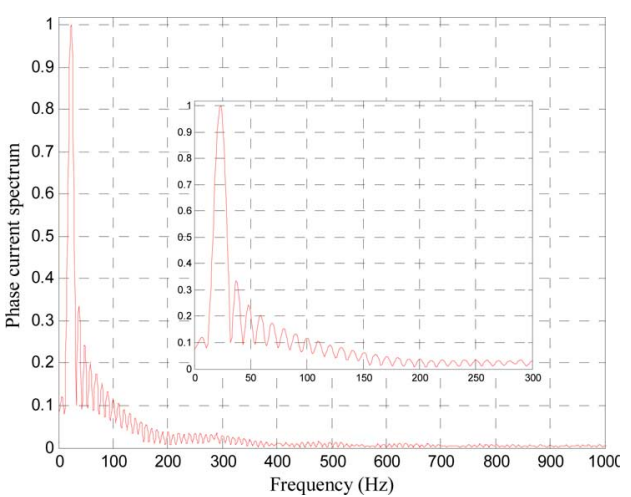

Fig. 13. Five-levels cascaded H-bridge inverter phase current fast Fourier transform (FFT) analysis.

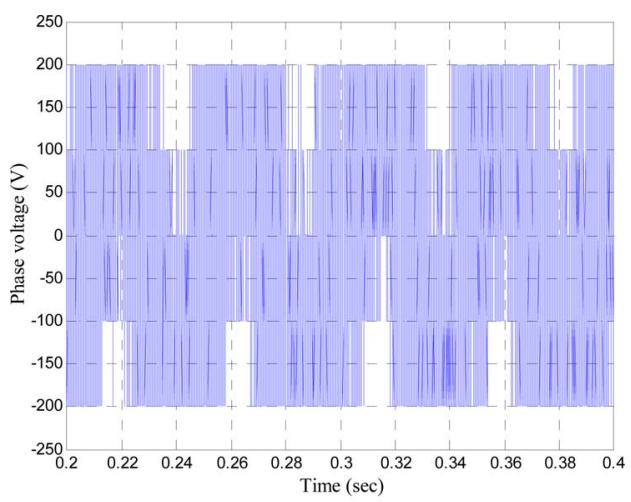

(a)

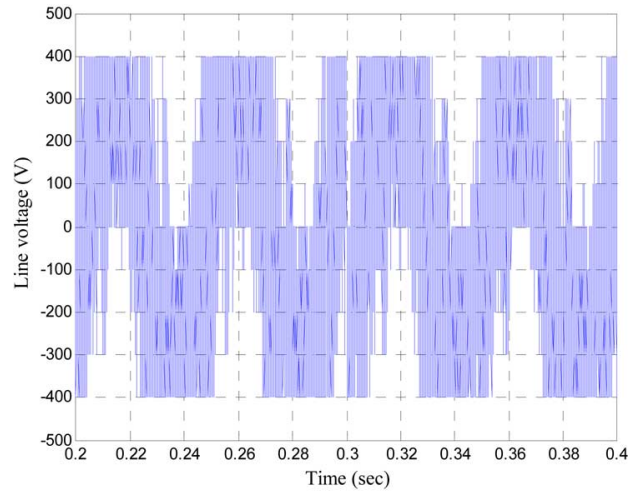

(b)

Fig. 14. Five-levels cascaded H-bridge inverter voltage waveforms. (a) Phase voltage. (b) Line voltage.

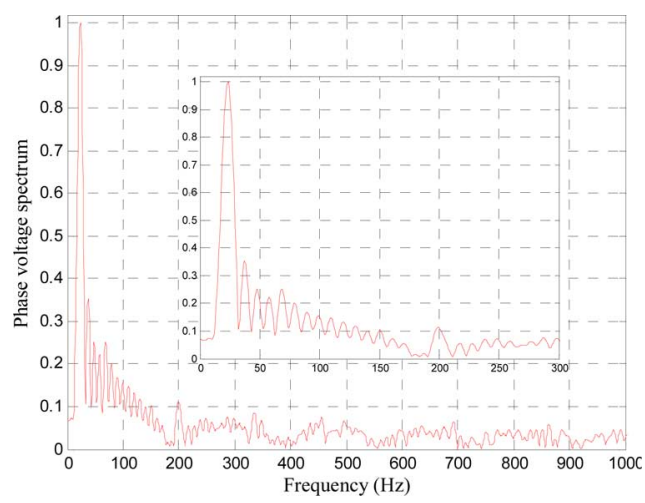

Fig. 15. Five-levels cascaded H-bridge inverter phase voltage FFT analysis.

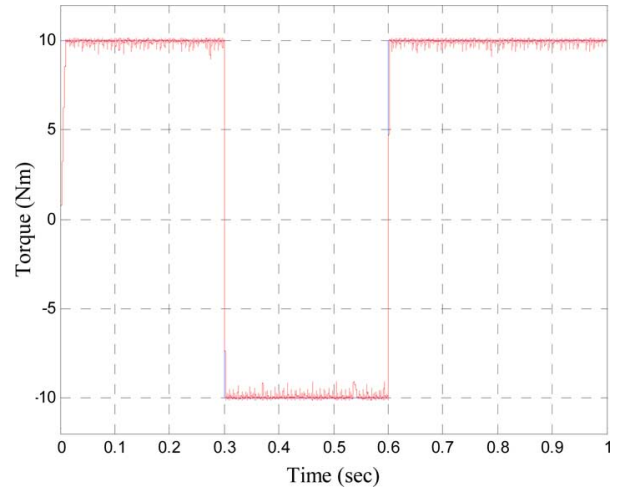

Fig. 16. Seven-levels cascaded H-bridge inverter estimated torque waveform. 


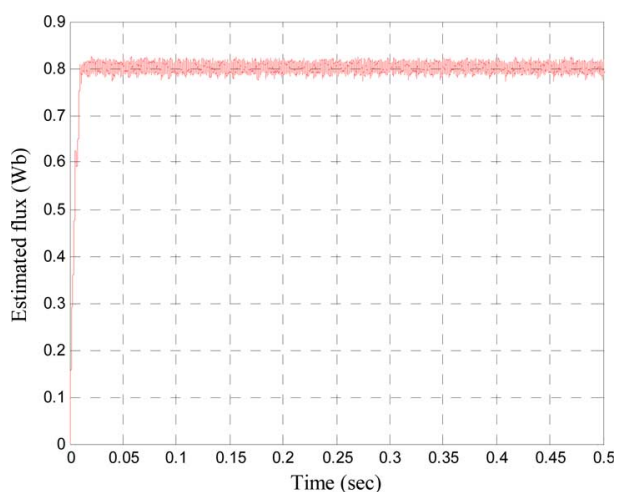

Fig. 17. Seven-levels cascaded H-bridge inverter stator flux waveform.

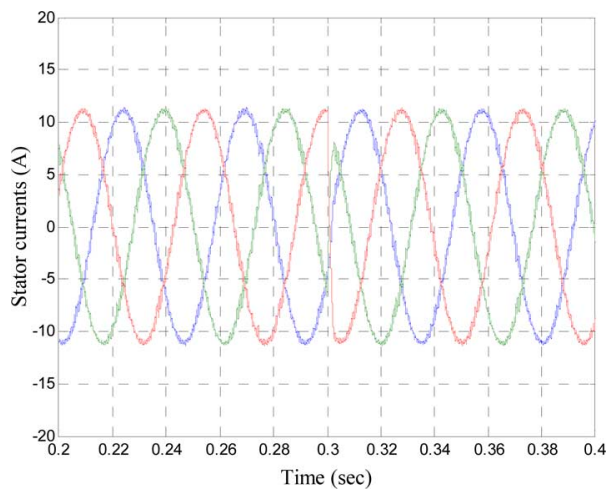

Fig. 18. Seven-levels cascaded H-bridge inverter output current waveform.

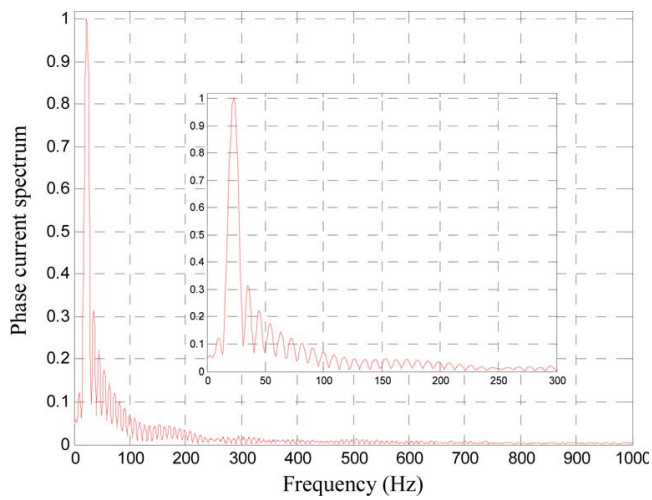

Fig. 19. Seven-levels cascaded H-bridge inverter phase current FFT analysis.

in the $\alpha-\beta$ frame is authorized per sampling period $T_{s}$. Hence, in the absence of inverter saturation, $Q^{k+1}$ must coincide with one of the six corners of the elementary hexagon centered at $Q^{k}$. The same procedure will be carried out at the next period in order to determine the next trajectory direction, yielding $Q^{k+2}$, which in turn will coincide with one of the six corners of the new elementary hexagon centered at $Q^{k+1}$. In case of inverter saturation (if $Q^{k}$ gives an unreachable point for $Q^{k+1}$ ), a trajectory correction is necessary (see Fig. 8). In cases (2) and (3), the closest displacement direction is selected. Case (1) illustrates a particular situation in which no switching should be performed, since the nearest reachable trajectory goes

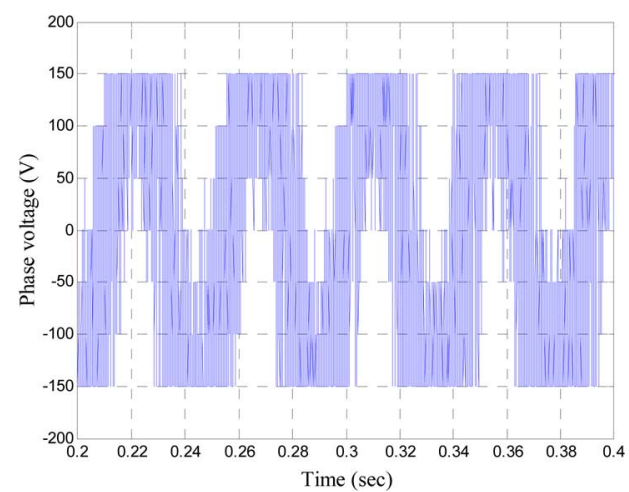

(a)

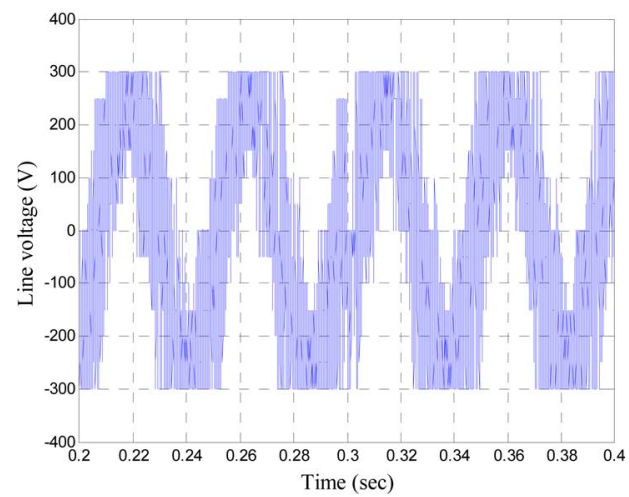

(b)

Fig. 20. Seven-levels cascaded H-bridge inverter voltage waveforms. (a) Phase voltage.(b) Line voltage.

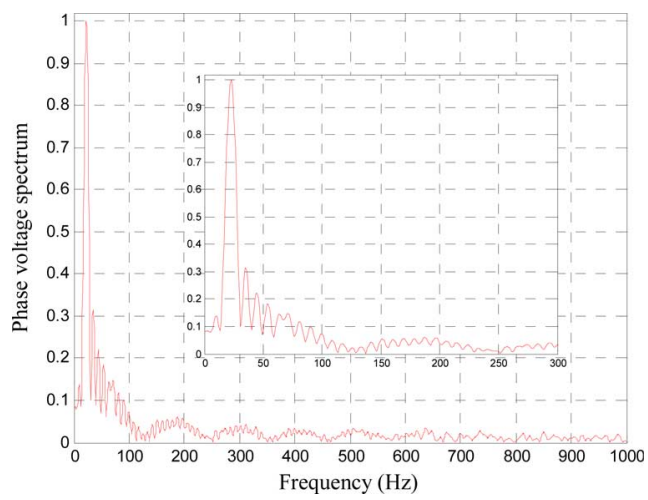

Fig. 21. Seven-levels cascaded H-bridge inverter phase voltage FFT analysis.

roughly toward the opposite sense of the favored one given by the lookup table (see Table II).

2) Second task: It exploits the degree of freedom related to the multilevel topology to choose the phase levels sequence that synthesizes the voltage vector selected previously. There are several phase levels sequences that are able to generate the same vector illustrated in Fig. 9; this degree of freedom can, therefore, be exploited to reduce voltage steps magnitude according to one of the following criteria: a) minimize the commutation number per period; b) distribute commutations for the three-phases per period; or c) choose a vector which minimizes the homopolar voltage. This task allows losses and torque ripple minimization. 


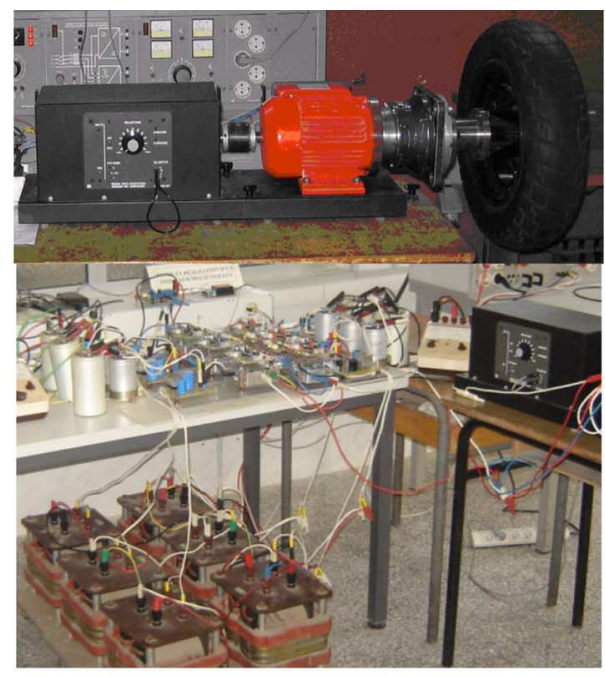

(a)

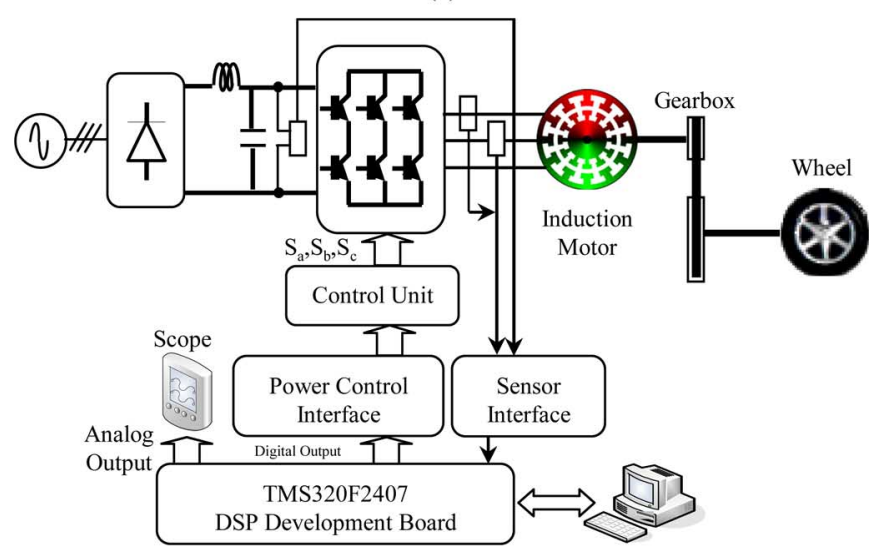

(b)

Fig. 22. Experimental setup.

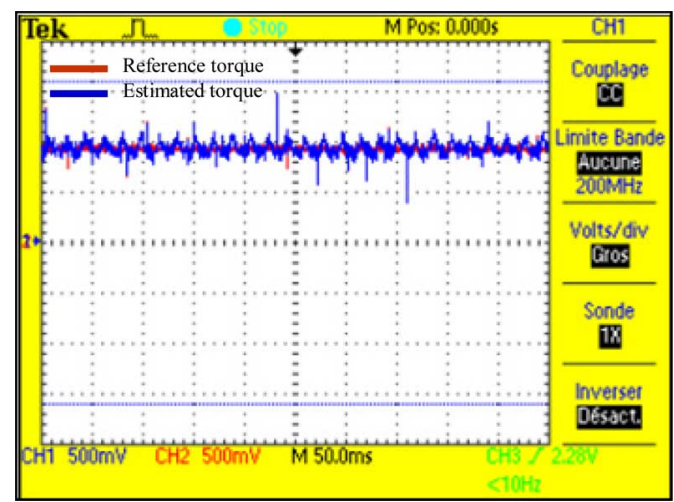

Fig. 23. Torque waveforms for a five-levels cascaded H-bridge.

Finally, the configuration of each phase will be selected and must be able to generate the phase levels.

\section{Simulation AND EXPERIMENTAL Results}

For the validation of the earlier discussed control approach, simulations and experiments have been carried out.

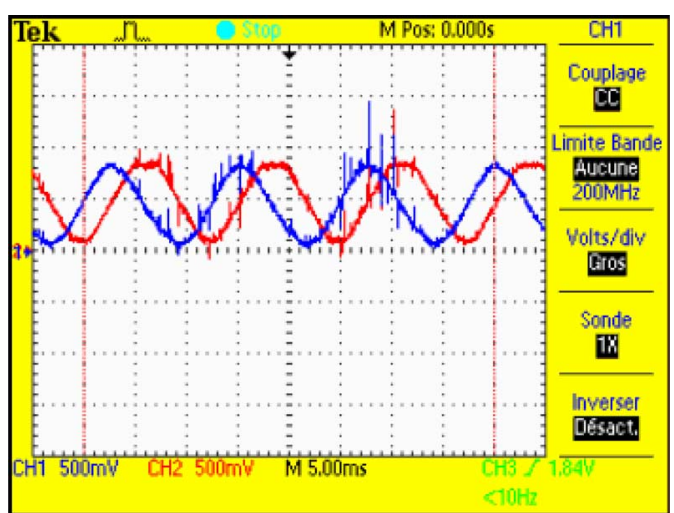

Fig. 24. $\alpha-\beta$ flux component waveforms for a five-levels cascaded H-bridge.

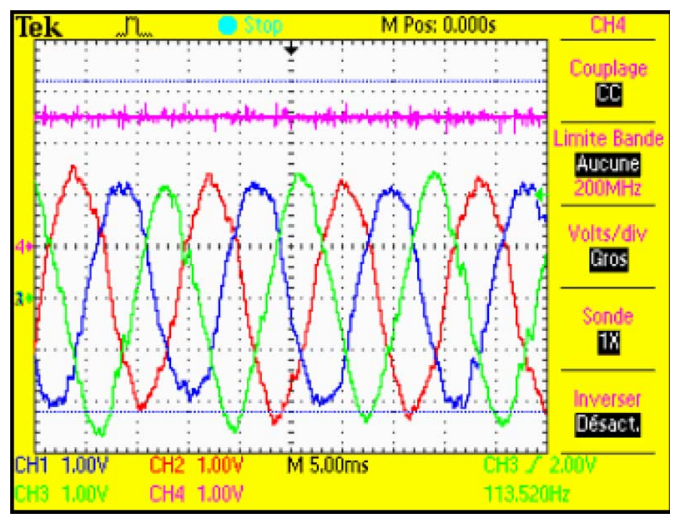

Fig. 25. Five-levels cascaded H-bridge inverter output current waveforms.

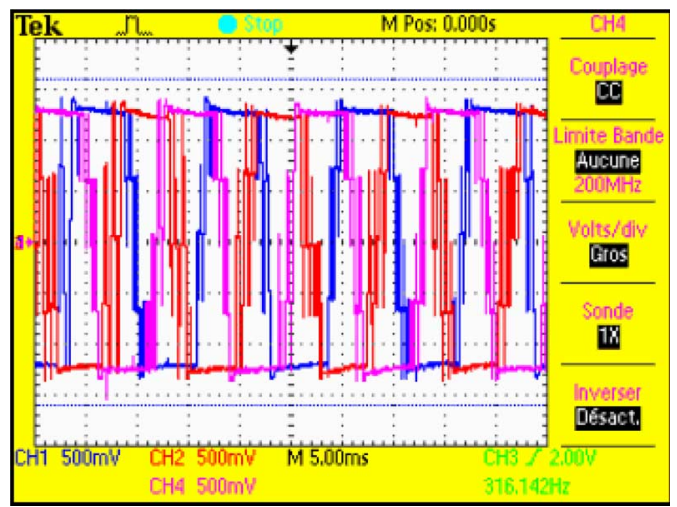

Fig. 26. Five-levels multilevel inverter output voltages during DTC.

Figs. $10-15$ and Figs. 16-21 show simulation results for fivelevels cascaded and seven-levels H-bridge inverter, respectively.

For further verification, a three-phase DSP (TMS320LF2407 A) controlled five- and seven-levels cascaded H-bridge multilevel DTC induction motor drive system prototype was built and tested (see Fig. 22). The induction motor ratings are given in the Appendix. The switch ratings are $(600 \mathrm{~V} / 27 \mathrm{~A})$ for the insulated gate bipolar transistors. The prototype is versatile; it consists of a multiwinding transformer and an inverter with a 


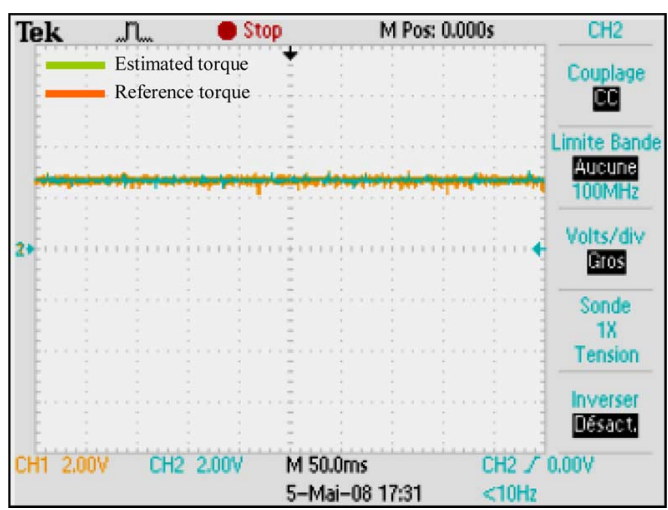

Fig. 27. Torque waveforms for seven-levels cascaded H-bridge.

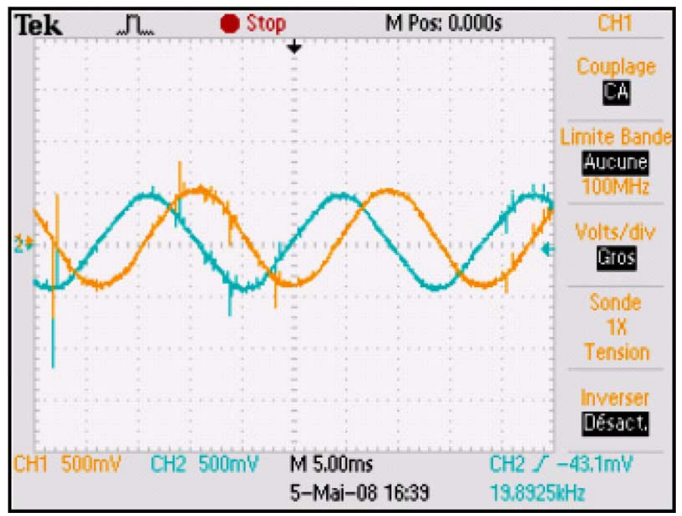

Fig. 28. $\quad \alpha-\beta$ flux component waveforms for a seven-levels cascaded H-bridge.

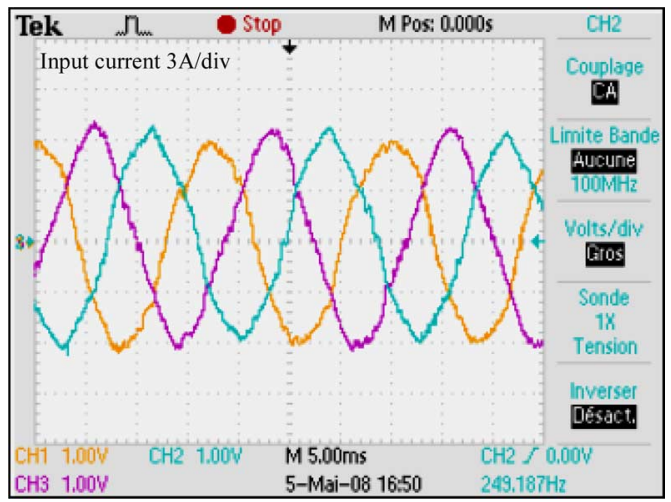

Fig. 29. Seven-levels cascaded H-bridge inverter output current waveforms.

burst structure that contains six H-bridges. The H-bridges and transformer terminals are connected through a single-phase rectifier with standard laboratory wires and connectors to get the tested, or any other desired, topology. The multilevel inverter control algorithms and the DTC are running in the same DSP. The control cycle is $120 \mu \mathrm{s}$.

It should be noted, as illustrated in Fig. 22(a), that the experimental setup was built to slightly emulate an automotive application (electric vehicle).

Figs. 23-26 and Figs. 27-30 illustrate experimental results for five-levels cascaded and seven-levels H-bridge inverter, respectively.

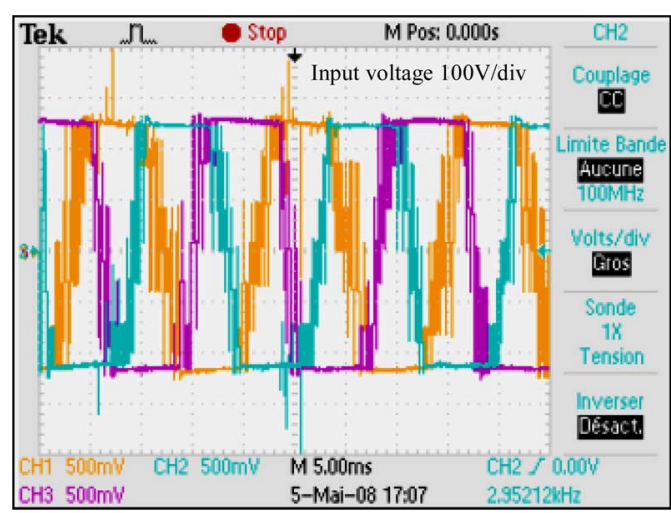

Fig. 30. Seven-levels multilevel inverter output voltages during DTC.

The output voltages form with seven-levels stepped multilevel waveform can be clearly appreciated; the motor currents complete the overview of the performance of the drive. They appear completely sinusoidal, since the low-pass nature of the load has filtered the high-frequency content of the applied voltage. The stator flux with constant amplitude imposed by the flux controller confirms the good dynamic performance of the drive. The most important results are that torque ripple has been almost eliminated in comparison to five-levels classic DTC.

\section{CONCLUSION}

This paper dealt with a comparison study for a cascaded $\mathrm{H}-$ bridge multilevel DTC induction motor drive. Indeed, symmetrical and asymmetrical arrangements of five- and seven-levels $\mathrm{H}$-bridge inverters have been compared in order to find an optimum arrangement with lower switching losses and optimized output voltage quality.

The carried out experiments shows that an asymmetrical configuration provides nearly sinusoidal voltages with very low distortion, using less switching devices. In addition, torque ripples are greatly reduced: asymmetrical multilevel inverter enables a DTC solution for high-power induction motor drives, not only due to the higher voltage capability provided by multilevel inverters, but mainly due to the reduced switching losses and the improved output voltage quality, which provides sinusoidal current without output filter.

\section{APPENDIX}

RATEd DATA of THE Simulated AND TeSTEd INDUCTION Motor

$1 \mathrm{~kW}, 50 \mathrm{~Hz}, 400 / 230 \mathrm{~V}, 3.4 / 5.9 \mathrm{~A}, 1420 \mathrm{rpm}$

$R_{s}=4.67 \Omega, R_{r}=8 \Omega, L_{s}=L_{r}=0.347 \mathrm{H}, M=0.366 \mathrm{H}$ $J=0.06 \mathrm{~kg} . \mathrm{m}^{2}, \beta=0.042 \mathrm{Nm} . \mathrm{sec}$

\section{REFERENCES}

[1] L. G. Franquelo, J. Rodriguez, J. I. Leon, S. Kouro, R. Portillo, and M. A. M. Prats, "The age of multilevel converters arrives," IEEE Ind. Electron. Mag., vol. 2, no. 2, pp. 28-39, Jun. 2008. 
[2] J. Rodriguez, L. G. Franquelo, S. Kouro, J. I. Leon, R. C. Portillo, M. A. M. Prats, and M. A. Perez, "Multilevel converters: An enabling technology for high-power applications," Proc. IEEE, vol. 97, no. 11, pp. 1786-1817, Nov. 2009.

[3] M. F. Escalante, J. C. Vannier, and A. Arzande, "Flying capacitor multilevel inverters and DTC motor drive applications," IEEE Trans. Ind. Electron., vol. 49, no. 4, pp. 805-815, Aug. 2002.

[4] T. Ishida, K. Matsuse, T. Miyamoto, K. Sasagawa, and L. Huang, "Fundamental characteristics of five-level double converters with adjustable DC voltages for induction motor drives," IEEE Trans. Ind. Electron., vol. 49, no. 4, pp. 775-782, Aug. 2002.

[5] Y. S. Lai and F. S. Shyu, "Topology for hybrid multilevel inverter," IEE Proc. Electr. Power Appl., vol. 149, no. 6, pp. 449-458, Nov. 2002.

[6] F. Khoucha, M. S Lagoun, K. Marouani, A. Kheloui, and M. E. H. Benbouzid, "Hybrid cascaded H-bridge multilevel inverter induction motor drive direct torque control for automotive applications," IEEE Trans. Ind. Electron., vol. 57, no. 3, pp. 892-899, Mar. 2010.

[7] C. Rech and J. R. Pinheiro, "Impact of hybrid multilevel modulation strategies on input and output harmonic performance," IEEE Trans. Power Electron., vol. 22, no. 3, pp. 967-977, May 2007.

[8] M. Veenstra and A. Rufer, "Control of a hybrid asymmetric multilevel inverter for competitive medium-voltage industrial drives," IEEE Trans. Ind. Appl., vol. 41, no. 2, pp. 655-664, Mar./Apr. 2005.

[9] P. C. Loh, P. C. G. H. Bode, and P. C. Tan, "Modular hysteresis current control of hybrid multilevel inverters," IEE Proc. Electr. Power Appl., vol. 152, no. 1, pp. 1-8, Jan. 2005.

[10] I. Boldea, "Control issues in adjustable speed drives," IEEE Ind. Electron Mag., vol. 2, no. 3, pp. 32-50, Sep. 2008

[11] G. S. Buja and R. Menis, "Steady-state performance degradation of a DTC IM drive under parameter and transduction errors," IEEE Trans. Ind. Electron., vol. 55, no. 4, pp. 1749-1760, Apr. 2008.

[12] G. S. Buja and M. P. Kazmierkowski, "Direct torque control of PWM inverter-fed AC motors-A survey," IEEE Trans. Ind. Electron., vol. 51, no. 4, pp. 744-757, Aug. 2004.

[13] D. Casadei, F. Profumo, G. Serra, and A. Tani, "FOC and DTC: Two viable schemes for induction motors torque control," IEEE Trans. Power Electron., vol. 17, no. 5, pp. 779-787, Sep. 2002.

[14] A. Haddoun, M. E. H. Benbouzid, and D. Diallo, "A loss-minimization DTC scheme for EV induction motors," IEEE Trans. Veh. Technol. vol. 56, no. 1, pp. 81-88, Jan. 2007.

15] F. Khoucha, M. S. Lagoun, A. Kheloui, and M. E. H. Benbouzid, "Symmetrical and asymmetrical H-bridge multilevel inverter for DTC induction motor drive automotive applications," in Proc. IEEE IECON2009, Porto, Portugal, Nov. 2009, pp. 1344-1349.

[16] M. Carpita, M. Marchesoni, M. Pellerin, and D. Moser, "Multilevel converter for traction applications: Small-scale prototype tests results," IEEE Trans. Ind. Electron., vol. 55, no. 5, pp. 2203-2212, May 2008.

[17] S. Lu, K. A. Corzine, and M. Ferdowsi, "A unique ultracapacitor direct integration scheme in multilevel motor drives for large vehicle propulsion," IEEE Trans. Veh. Technol., vol. 56, no. 4, Part 1, pp. 1506-1515, Jul. 2007.

[18] M. Manjrekar and T. A. Lipo, "A hybrid multilevel inverter topology for drive application," in Proc. IEEE APEC1998, Anaheim, CA, Feb., pp. $523-529$.

[19] A. Rufer, M. Veenstra, and K. Gopakumar, "Asymmetric multilevel converter for high resolution voltage phasor generation," in Proc. EPE, Lausanne, Switzerland, Sep.1999.

[20] X. del Toro Garcia, A. Arias, M. G. Jayne, and P. A. Witting, "Direct torque control of induction motors utilizing three-level voltage source inverters," IEEE Trans. Ind. Electron., vol. 55, no. 2, pp. 965-958, Feb. 2008.

[21] J. Rodriguez, J. Pontt, S. Kouro, and P. Correa, "Direct torque control with imposed switching frequency in an 11-level cascaded inverter," IEEE Trans. Ind. Electron., vol. 51, no. 4, pp. 827-833, Aug. 2008.

[22] S. Kouro, R. Bernal, H. Miranda, C. A. Silva, and J. Rodriguez, "Highperformance torque and flux control for multilevel inverter fed induction motors," IEEE Trans. Power Electron., vol. 22, no. 6, pp. 2116-2123, Nov. 2007.

[23] F. Khoucha, K. Marouani, A. Kheloui, and M. E. H. Benbouzid, "A minimization of speed ripple of sensorless DTC for controlled induction motors used in electric vehicles," in Proc. IEEE IECON2006, Paris, France, Nov., pp. 1339-1344.

[24] F. Khoucha, K. Marouani, A. Haddoun, A. Kheloui, and M. E. H. Benbouzid, "An improved sensorless DTC scheme for EV induction motors," in Proc. IEEE IEMDC2007, Antalya, Turkey, vol. 2, pp. 1159-1164, May 2007.

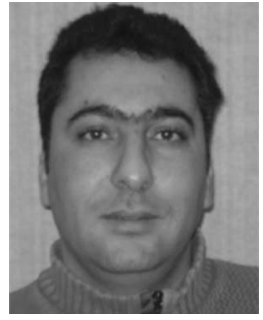

Farid Khoucha was born in Khenchela, Algeria, in 1974. He received the B.Sc. and M.Sc. degrees in electrical engineering, in 1998 and 2003, respectively, from the Polytechnic Military Academy, Algiers, Algeria, where he is currently working toward the Ph.D. degree in electric- and hybrid-vehicle control and power management in collaboration with the University of Brest, Brest, France.

Since 2000, he has been with the Electrical Engineering Department, Polytechnic Military Academy, where he joined as a Teaching Assistant. He is also with the Laboratoire Brestois de Mécanique et des Systèmes (EA 4325), University of Brest.

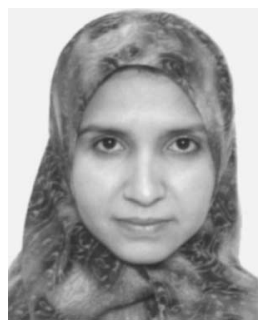

Mouna Soumia Lagoun was born in Djelfa, Algeria, in 1982. She received the B.Sc. degree in electrical engineering from the University of Djelfa, Djelfa, in 2004, and the M. Sc. degree in electrical engineering from the Polytechnic Military Academy, Algiers, Algeria, in 2008. She is currently working toward the $\mathrm{Ph} . \mathrm{D}$. degree in renewable energy systems at the University of Laghouat, Laghouat, Algeria, in collaboration with the University of Brest, Brest, France.

She is currently a Teaching Assistant at the University of Laghouat. She is also with the Laboratoire Brestois de Mécanique et des Systèmes (EA 4325), University of Brest. Her research interests include the control of electrical drives and power electronics.

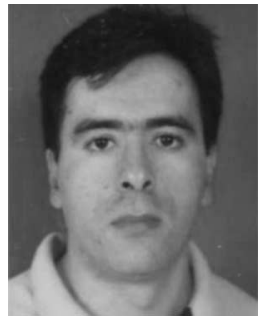

Abdelaziz Kheloui received the M.Sc. degree in electrical engineering from the Ecole Nationale d'Ingénieurs et Techniciens of Algeria (ENITA), Algiers, Algeria, in 1990, and the Ph.D. degree in electrical engineering from the National Polytechnic Institute of Lorraine, Nancy, France, in 1994.

Since 1994, he has been an Assistant then an Associate Professor at the Electrical Engineering Department, Polytechnic Military Academy, Algiers, Algeria. His current research interests include control of electrical drives and power electronics.

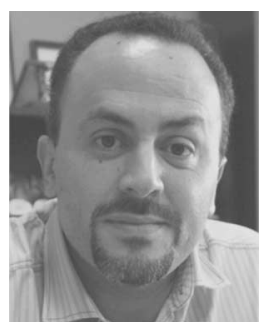

Mohamed El Hachemi Benbouzid (S'92-M'95SM'98) was born in Batna, Algeria, in 1968. He received the B.Sc. degree in electrical engineering from the University of Batna, Batna, Algeria, in 1990 the M.Sc. and Ph.D. degrees in electrical and computer engineering from the National Polytechnic Institute of Grenoble, Grenoble, France, in 1991 and 1994, respectively, and the Habilitation à Diriger des Recherches degree from the University of Picardie "Jules Verne," Amiens, France, in 2000.

After receiving the $\mathrm{Ph}$. $\mathrm{D}$. degree, he joined the Professional Institute of Amiens, University of Picardie "Jules Verne," where he was an Associate Professor of electrical and computer engineering. Since September 2004, he has been with the Institut Universitaire de Technologie of Brest, University of Brest, Brest, France, where he is currently a Professor of electrical engineering. His research interests and experience include analysis, design, and control of electric machines, variable-speed drives for traction, propulsion, and renewable energy applications, and fault diagnosis of electric machines.

Prof. Benbouzid is a Senior Member of the IEEE Power Engineering, the IEEE Industrial Electronics, the IEEE Industry Applications, the IEEE Power Electronics, and the IEEE Vehicular Technology Societies. He is an Associate Editor of the IEEE TRANSACTIONS ON ENERGY CONVERSION, the IEEE TRANSACTIONS ON INDUSTRIAL ELECTRONICS, the IEEE TRANSACTIONS ON VEHICULAR TECHNOLOGY, and the IEEE/ASME TRANSACTIONS ON MECHATRONICS. 